Journal of Physical Science, Vol. 29(Supp. 2), 159-173, 2018

\title{
Effect of Water Content and Water Type on the Physical Properties of Concrete
}

\author{
Elviana, ${ }^{*}$ Ashar Saputra and Djoko Sulistyo \\ Department of Civil Engineering and Environment, Faculty of Engineering, Universitas \\ Gadjah Mada, Jalan Grafika No.2, Sinduadi, Mlati, Sleman, Yogyakarta 55284, Indonesia \\ ${ }^{*}$ Corresponding author: margarethaelviana27@gmail.com
}

Published online: 30 July 2018

To cite this article: Elviana, Saputra, A. \& Sulistyo, D. (2018). Effect of water content and water type on the physical properties of concrete. J. Phys. Sci., 29(Supp. 2), 159-173, https://doi.org/10.21315/jps2018.29.s2.12

To link to this article: https://doi.org/10.21315/jps2018.29.s2.12

\begin{abstract}
Reinforced concrete buildings are the preferred choice of water constructions such as harbour, dock, offshore construction, and other seawater structures that cannot be separated from the influence of adhesive environments. Adhesive environment can lead to expansion and corrosion. Furthermore, crystallisation of salt content in reinforced concrete pores can even lead to a decrease in reinforced concrete strength. This study aims to determine the effect of seawater content on the physical properties of concrete. The study was carried out on cylindrical test specimens with $150 \mathrm{~mm}$ and $300 \mathrm{~mm}$ diameter in wet and dry conditions immersed in seawater from the Indian Ocean (Trisik Beach, Indonesia). The specimens were tested after 28 days and 90 days. The comparator used a freshwater-immersed concrete cylinders test object. The results showed that after 28 days, the concrete strength of concrete immersed in seawater increased, but after 90 days, the strength decreased. Wet conditions on concrete will reduce the strength of concrete.
\end{abstract}

Keywords: Water content, water type, properties of concrete, reinforced concrete, seawater

\section{INTRODUCTION}

Reinforced concrete material has become the main choice in the construction of main and complementary water structures. Harbour projects, docks, offshore construction structures, and other seawater structures cannot be separated from the influence of aggressive environments, which consist of the effects of seawater, air and solutions containing sulphate salts chloride, sulphuric acid and other additives. The most serious effect of seawater on reinforced concrete structure 
is the salt $(\mathrm{NaCl})$ reaction. Salt triggers expansion, corrosion and crystallisation of salt content in reinforced concrete pores that have certain permeability value. Furthermore, it may lead to a decrease in the strength of concrete bond. ${ }^{1}$

Based on research, the salt content in the process of making concrete may reduce the compressive strength of concrete by up to $8 \% .^{2}$ Mehta and Monteiro describe in detail how the chemical reactions occur between the salt elements contained in seawater, such as calcium chloride and magnesium chloride, and cement and hydration process. These elements may cause reduction in setting time. ${ }^{1}$ At first, the compressive strength of the concrete will be increased with the formation of Friedel's salt, which is the result of the binding of chloride in the concrete as the salt fills the pores of the concrete. Chloride content in seawater can result in a reduction of $\mathrm{Ca}(\mathrm{OH})_{2}$ in the concrete, causing an increase in compressive strength. ${ }^{1}$ If the reaction happens for a longer period of time, strength will decrease and sulphate concentration in seawater can cause damage to the paste. In addition to these chemical reactions, if there is any surface which is in direct contact with the salt solution, the material will be damaged by the pressure caused by crystallisation of salt content in the pores which suppresses the pores of concrete walls. Due to the pressure, the concrete will break into small pieces.

The researchers examined the effect of seawater content on the strength of concrete in wet and dry conditions. As a comparison to the effect of seawater content on concrete, the researchers performed a test using fresh water. The observation used by the researchers is the physical nature caused by aggressive environment which, according to some theories, affects the strength of concrete by chemical and physical reactions.

\section{LITERATURE REVIEW}

\subsection{The Effect of Seawater Content on Concrete}

The salt content in seawater consists of several components, namely $\mathrm{NaCl}, \mathrm{MgCl}_{2}$ and $\mathrm{MgSO}_{4}$. It is very dangerous for seawater to come in contact with concrete during curing period because the concrete will absorb sea salt as the capillary action fills the pores of the concrete. This compound will result in loss of mass and strength, and acceleration of weathering process that reduce the service life of the concrete. $^{3}$

Abualgasem et al. control the environmental influences that contain sulphate on concrete. The losses of mass and size of beam were observed. The first signs of 
size change in concrete occur in 84 days, followed by the appearance of cracks. ${ }^{4}$ The mechanism of damage caused by sulphur on concrete that receives loads in wet and dry conditions based on micro and macro observations was investigated by Gao et al. ${ }^{5}$ The research was conducted to determine the effects of action and reaction that happen in wet and dry conditions and the effect of crystallisation. In dry condition, the moisture which is reduced by evaporation makes salt crystallise faster. Salt crystals fill the pores of concrete to provide pressure that can aggravate the strength of the concrete. ${ }^{5}$

Wegian investigated the effects of mixing and curing concrete with seawater on the compressive, tensile, flexural and bond strengths of concrete. Concrete mixes were prepared by varying coarse aggregate, cement proportions and types. Concrete were cured in fresh water and seawater. The compressive strength increased for specimens mixed and cured in seawater at early ages up to 14 days, while a definite decrease in the respective strengths was observed for age more than 28 days up to 90 days. ${ }^{6}$

Mehta and Monteiro describe in detail how the chemical reactions that occur between the salt elements contained in seawater, such as calcium chloride and magnesium chloride, and cement and hydration process reduce the setting time. ${ }^{1}$ The clinker on Portland Cement contains four major chemical compounds: tricalcium silicate $\left(\mathrm{C}_{3} \mathrm{~S}\right.$ or $\left.3 \mathrm{CaO} . \mathrm{SiO}_{2}\right)$; dicalsium silicate $\left(\mathrm{C}_{2} \mathrm{~S}\right.$ or $\left.2 \mathrm{CaO} . \mathrm{SiO}_{2}\right)$; tricalcium aluminate $\left(\mathrm{C}_{3} \mathrm{~A}\right.$ or $\left.3 \mathrm{CaO} . \mathrm{Al}_{2} \mathrm{O}_{3}\right)$; and tentrakalsium aliminoferrit $\left(\mathrm{C}_{4} \mathrm{AF}\right.$ or $\left.4 \mathrm{CaO} \cdot \mathrm{Al}_{2} \mathrm{O}_{3} \cdot \mathrm{Fe}_{2} \mathrm{O}_{3}\right)$.

Each of these chemical compositions will react with water, causing hydration reactions of the following chemical formulas: tricalcium silicate tobermorite calcium hydroxide gel, dicalcium silicate gel tobermorite calcium hydroxide, tricalcium aluminate gypsum ettringite, tricalcium aluminate calcium aluminate hydrate, and tentrakalsium alumino-ferrite calcium aluminoferrite hydrate. $\mathrm{C}_{3} \mathrm{~S}$ and $\mathrm{C}_{2} \mathrm{~S}$ are the most dominant compounds in cement and play a role in increasing its strength, while $\mathrm{C}_{3} \mathrm{~A}$ and $\mathrm{C}_{4} \mathrm{AF}$ act as the cementation catalysts of heat cement. Chemically, one of the cement hydration products is $\mathrm{Ca}(\mathrm{OH})_{2}$. This compound easily reacts to anything in the water content. On the other hand, $\mathrm{Ca}(\mathrm{OH})_{2}$ serves to protect galvanised steel from corrosion, meaning it maintains the passive nature of steel. Below are the chemical reactions of the hydration process that occur on cement when reacting to the chloride of seawater:

Hydration that occurs in $\mathrm{C}_{3} \mathrm{~S}$ produces:

$$
3 \mathrm{CaO} .2 \mathrm{SiO}_{2} .3 \mathrm{H}_{2} \mathrm{O}+3 \mathrm{Ca}(\mathrm{OH})_{2}
$$


Hydration that occurs in $\mathrm{C}_{2} \mathrm{~S}$ produces:

$$
3 \mathrm{CaO} .2 \mathrm{SiO}_{2} .2 \mathrm{H}_{2} \mathrm{O}+\mathrm{Ca}(\mathrm{OH})_{2}
$$

$\mathrm{C}_{3} \mathrm{~S}$ (tricalcium silicate) and $\mathrm{C}_{2} \mathrm{~S}$ (dicalcium silicate) are two of the four chemical compounds of cement. When $\mathrm{Ca}(\mathrm{OH})_{2}$ reacts with $\mathrm{NaCl}$ from seawater, the following reaction occurs:

$$
2 \mathrm{NaCl}+\mathrm{Ca}(\mathrm{OH})_{2} \rightarrow \mathrm{CaCl}_{2}+2 \mathrm{NaOH}
$$

$\mathrm{CaCl}_{2}$ will react with one of the chemical compositions of cement, i.e., $\mathrm{C}_{3} \mathrm{~A}$, and produce Friedel's salt. Cement hydration produces calcium hydroxide and calcium aluminate hydrate. Calcium hydroxide is alkaline, hence the concrete is sensitive to sulphate salt. The reaction between magnesium sulphate and calcium hydroxide will produce gypsum. $\mathrm{CaSO}_{4}$ reacts with $\mathrm{C}_{3} \mathrm{~A}$ from cement and water to form ettringite. ${ }^{1}$

Similarly, like rust on iron, the ettringite that occurs increases the volume of concrete, pushing the mass of concrete and causing rupture. At first, the compressive strength of the concrete will be increased by the formation of Friedel's salt which is resulted from binding chloride in the concrete. Chloride content in seawater can reduce $\mathrm{Ca}(\mathrm{OH})_{2}$ in the concrete causing an increase in compressive strength. If $\mathrm{Ca}(\mathrm{OH})_{2}$ is applied for a longer period of time, the strength will decrease and sulphate concentration in seawater can cause damage to the paste. In addition to these chemical reactions, if there is any surface which is in direct contact with the salt solution, the material will be damaged by the pressure caused by crystallisation of salt content in the pores which suppresses the pores of concrete walls. Due to the pressure, the concrete will break into small pieces.

\subsection{The Effect of Wet and Dry Conditions on Concrete Strength}

Neville reported that concrete immersion process can be used as a concrete treatment. ${ }^{3}$ Immersion serves to help the cement hydration process, controlling temperature and moisture level in concrete so that it is in water saturated condition. The required moisture level of concrete to be able to continue the hydration process is no less than $80 \%$ with temperature.

Wet and dry conditions of concrete affect the strength of the concrete. Soroka and Baum have proven that dry condition of concrete has around $13 \%$ better strength than wet conditions. Wet and dry conditions are distinguished by humidity and temperature. ${ }^{7}$ Abualgasem et al. performed wet and dry tests for 18 months. The 
time required to achieve dry conditions is 10 days to 1 month. The ratio of the periods required to achieve dry and wet conditions is 1:3. ${ }^{4}$

\section{EXPERIMENTAL}

This research used an experimental method with the aim to determine the effect of seawater content on the physical properties of concrete. The tests conducted in this study included concrete forming materials, immersion in seawater, and compressive strength using concrete cylindrical test specimens in wet and dry conditions. Cylindrical test specimens with $150 \mathrm{~mm}$ diameter and $300 \mathrm{~mm}$ diameter were tested with a $2000 \mathrm{kN}$ Compression Testing Machine (CTM) to determine the amount of compressive strength of the concrete. The amount of strain that occurred was read using a set of concrete strain reader dial with $0.01-10 \mathrm{~mm}$ precision.

Normal concrete mix was made manually using Indonesian National Standard (SNI) 03:2834:2000 alloy, the reinforced plan was $25 \mathrm{MPa}$. The range of the rough aggregate size was $10 \mathrm{~mm}$ to $19 \mathrm{~mm}$. The cement used in making normal concrete mix was Pozzolana Portland Cement (PPC). FAS value in making concrete mixture was 0.5 . The proportion of fine aggregate weight to the mixture was $30 \%$. After $1-2$ days of concrete casting, specimens were cured. Concrete treatment was done to keep the fresh concrete surfaces moist. Concrete surface moisture was maintained to ensure that the cement hydration process proceeded perfectly, increasing the resistance of the concrete to weather, and making the concrete more waterproof. Water immersion was performed as a comparison with seawater immersion. Immersion was performed for 28 days and 90 days.

In dry specimens, the test object is left at room temperature until it reached the saturated surface dry (SSD) condition. The test specimens were set to have around $90 \%$ humidity approximately. Variations of the specimens used in concrete compressive strength test after immersion can be seen in Table 1. 
Table 1: Variations of concrete cylinder test materials.

\begin{tabular}{lccc}
\hline \multirow{2}{*}{ Code } & \multicolumn{2}{c}{ Amount } & \multicolumn{2}{c}{$\begin{array}{c}\text { Age of concrete } \\
\text { (Day) }\end{array}$} \\
\cline { 2 - 4 } & Immersed in seawater & Immersed in fresh water & 28 \\
$\mathrm{SB}-\mathrm{B}$ & 3 & 3 & 28 \\
$\mathrm{SB}-\mathrm{K}$ & 3 & 3 & 90 \\
$\mathrm{SB}-\mathrm{B}$ & 3 & 3 & 90 \\
$\mathrm{SB}-\mathrm{K}$ & 3 & 3 & \\
\hline
\end{tabular}

Notes: $S B-B=$ concrete cylinder in wet conditions; $S B-K=$ concrete cylinder in dry condition

\section{RESULTS AND DISCUSSION}

\subsection{Compression Strength of Concrete}

The results of compressive strength test for 28 days and 90 days of each variation can be seen in Tables 2 and 3 respectively. The compressive strength of concrete was tested using concrete cylinders specimens with $30 \mathrm{~cm}$ height and $15 \mathrm{~cm}$ diameter. During the compressive strength test, strain was observed. The strain observation was performed to describe the comparison between the stress and strain curves of concrete to determine the amount of elastic modulus. The amount of elastic modulus of concrete is obtained from the stress and strain curves. Strain $(\varepsilon)$ is obtained from comparing the shortening $(\Delta \mathrm{L})$ with the initial length of the cylinder (1). The strain curves of the concrete cylinders at various conditions on day 28 can be seen in Figures 1 to 4 . The strain curves of the concrete cylinders at various conditions to calculate the elastic modulus of concrete on day 90 can be seen in Figures 5 to 8.

Table 2: Compression strength of concrete on day 28.

\begin{tabular}{|c|c|c|c|c|c|c|c|}
\hline \multirow[t]{2}{*}{ Number } & \multirow[t]{2}{*}{ Code } & $\begin{array}{c}\text { Age } \\
\text { of } \\
\text { object }\end{array}$ & $\begin{array}{l}\text { Load } \\
\text { (P) }\end{array}$ & $\begin{array}{l}\text { Compression } \\
\text { strength }\end{array}$ & $\begin{array}{c}\text { Average } \\
\text { compression } \\
\text { strength }\end{array}$ & \multirow[t]{2}{*}{$\begin{array}{l}\text { Modulus } \\
\text { elasticity }\end{array}$} & \multirow[t]{2}{*}{$\begin{array}{c}\text { Average of } \\
\text { modulus } \\
\text { elasticity }\end{array}$} \\
\hline & & (Day) & $(\mathrm{kN})$ & $(\mathrm{MPa})$ & (MPa) & & \\
\hline 1 & SA1K & 28 & 510 & 27.24 & & 24529.61 & \\
\hline 2 & SA2K & 28 & 490 & 27.43 & 28.41 & 24617.82 & 25042.87 \\
\hline 3 & SA3K & 28 & 540 & 30.56 & & 25981.16 & \\
\hline 4 & SL1K & 28 & 550 & 31.12 & & 26220.62 & \\
\hline 5 & SL2K & 28 & 520 & 29.04 & 29.42 & 25326.64 & 25487.49 \\
\hline 6 & SL3K & 28 & 490 & 28.10 & & 24915.22 & \\
\hline
\end{tabular}


Table 2: (continued)

\begin{tabular}{|c|c|c|c|c|c|c|c|}
\hline \multirow[t]{2}{*}{ Number } & \multirow[t]{2}{*}{ Code } & $\begin{array}{c}\text { Age } \\
\text { of } \\
\text { object }\end{array}$ & $\begin{array}{l}\text { Load } \\
(\mathrm{P})\end{array}$ & $\begin{array}{l}\text { Compression } \\
\text { strength }\end{array}$ & $\begin{array}{c}\text { Average } \\
\text { compression } \\
\text { strength }\end{array}$ & \multirow[t]{2}{*}{$\begin{array}{l}\text { Modulus } \\
\text { elasticity }\end{array}$} & \multirow{2}{*}{$\begin{array}{c}\text { Average of } \\
\text { modulus } \\
\text { elasticity }\end{array}$} \\
\hline & & (Day) & $(\mathrm{kN})$ & (MPa) & (MPa) & & \\
\hline 7 & SL1B & 28 & 460 & 25.42 & & 23695.18 & \\
\hline 8 & SL2B & 28 & 420 & 23.93 & 25.22 & 22989.86 & 23598.37 \\
\hline 9 & SL3B & 28 & 425 & 26.31 & & 24110.06 & \\
\hline 10 & SA1B & 28 & 375 & 21.22 & & 21650.97 & \\
\hline 11 & SA2B & 28 & 450 & 25.40 & 23.19 & 23685.86 & 22618.51 \\
\hline 12 & SA3B & 28 & 410 & 22.96 & & 22518.71 & \\
\hline
\end{tabular}

Notes: $S A I K-S A 3 K=$ Dry cured freshwater cylinder; $S L I K-S L 3 K=$ Dry cured seawater cylinder; SLIB $-S L 3 B$ $=$ Wet cured seawater cylinder; $S A I B-S A 3 B=$ Wet cured freshwater cylinder

Table 3: Compression strength of concrete on day 90.

\begin{tabular}{|c|c|c|c|c|c|c|c|}
\hline \multirow[t]{2}{*}{ Number } & \multirow[t]{2}{*}{ Code } & $\begin{array}{c}\text { Age of } \\
\text { object }\end{array}$ & $\begin{array}{l}\text { Load } \\
(\mathrm{P})\end{array}$ & $\begin{array}{c}\text { Compression } \\
\text { strength }\end{array}$ & $\begin{array}{l}\text { Average of } \\
\text { compression } \\
\text { strength }\end{array}$ & \multirow[t]{2}{*}{$\begin{array}{l}\text { Modulus } \\
\text { elasticity }\end{array}$} & \multirow{2}{*}{$\begin{array}{l}\text { Average } \\
\text { of } \\
\text { modulus } \\
\text { elasticity }\end{array}$} \\
\hline & & (Day) & $(\mathrm{kN})$ & (MPa) & $(\mathrm{MPa})$ & & \\
\hline 1 & SA1K & 90 & 560 & 31.15 & & 26230.59 & \\
\hline 2 & SA2K & 90 & 550 & 31.12 & 30.19 & 26220.62 & 25817.20 \\
\hline 3 & SA3K & 90 & 500 & 28.29 & & 25000.38 & \\
\hline 4 & SL1K & 90 & 440 & 24.67 & & 23343.50 & \\
\hline 5 & SL2K & 90 & 520 & 29.43 & 26.85 & 25495.49 & 24337.30 \\
\hline 6 & SL3K & 90 & 460 & 26.45 & & 24172.91 & \\
\hline 7 & SL1B & 90 & 460 & 26.03 & & 23979.52 & \\
\hline 8 & SL2B & 90 & 380 & 21.47 & 24.27 & 21780.31 & 23132.83 \\
\hline 9 & SL3B & 90 & 450 & 25.30 & & 23638.65 & \\
\hline 10 & SA1B & 90 & 510 & 28.86 & & 25249.15 & \\
\hline 11 & SA2B & 90 & 435 & 24.65 & 27.27 & 23334.36 & 24527.54 \\
\hline 12 & SA3B & 90 & 490 & 28.29 & & 24999.11 & \\
\hline
\end{tabular}

Notes: $S A I K-S A 3 K=$ dry cured freshwater cylinder; $S L I K-S L 3 K=$ dry cured seawater cylinder; $S L I B-S L 3 B$ $=$ wet cured seawater cylinder; $S A I B-S A 3 B=$ wet cured freshwater cylinder. 


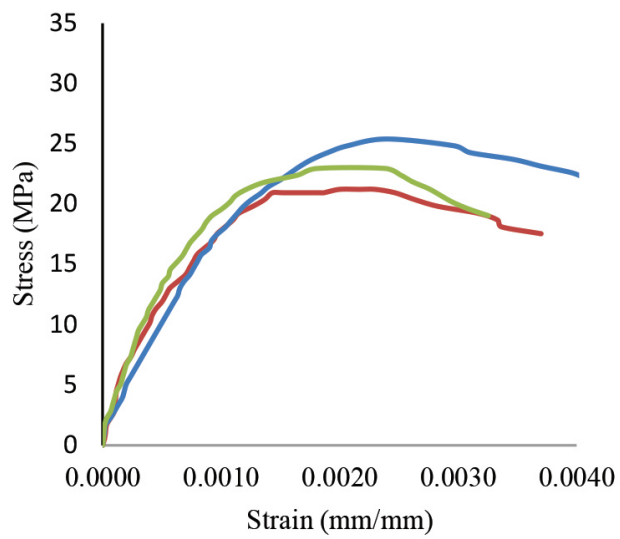

$\longrightarrow$ SA1B $\longrightarrow$ SA2B $\longrightarrow$ SA3B

Figure 1: Stress and strain diagram of cylinder immersed in fresh water in wet condition for 28 days.

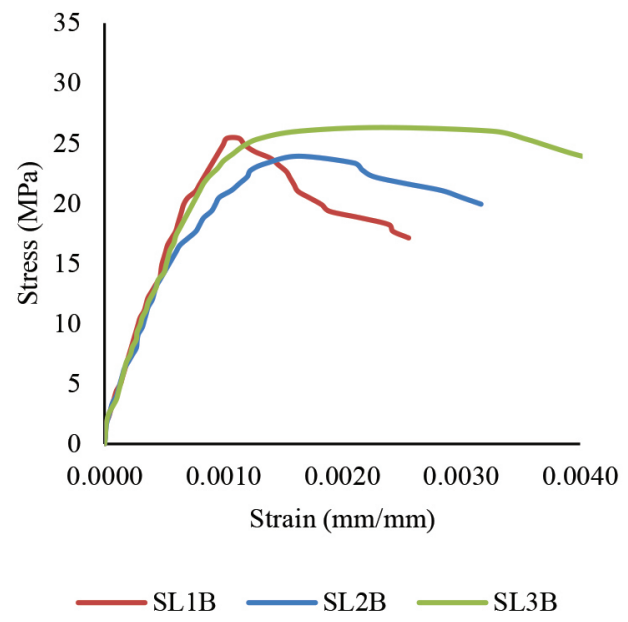

Figure 2: Stress and strain diagram of cylinder immersed in seawater in wet condition for 28 days. 


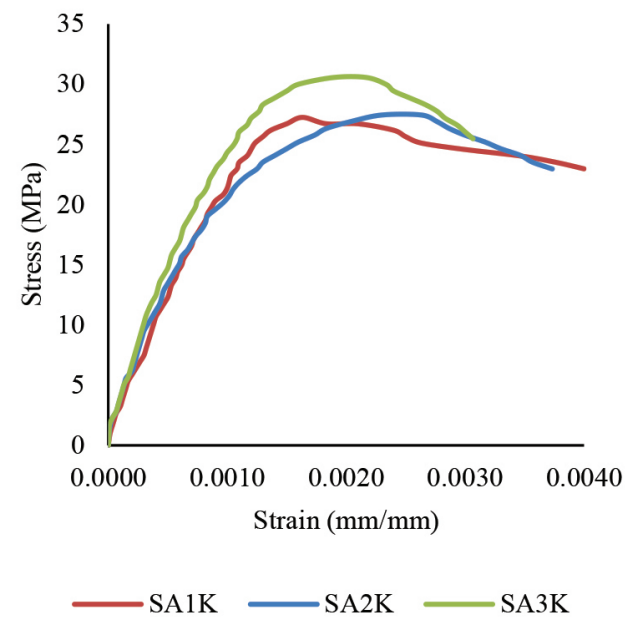

Figure 3: Stress and strain diagram of cylinder immersed in fresh water in dry condition for 28 days.

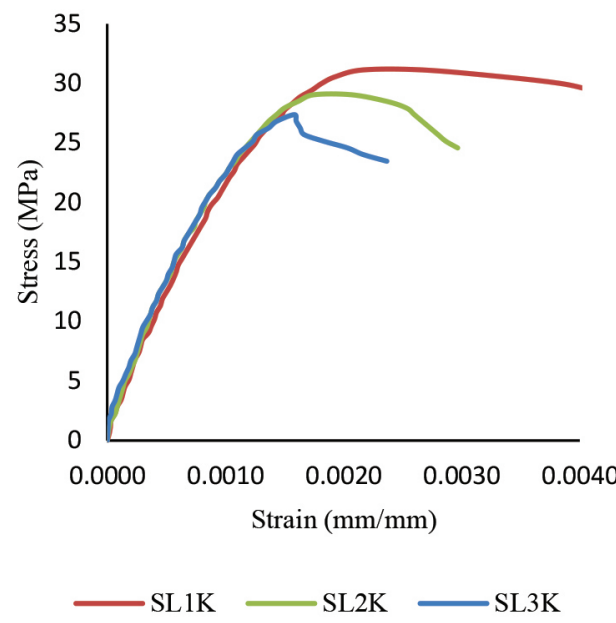

Figure 4: Stress and strain diagram of cylinder immersed in seawater in dry condition for 28 days. 


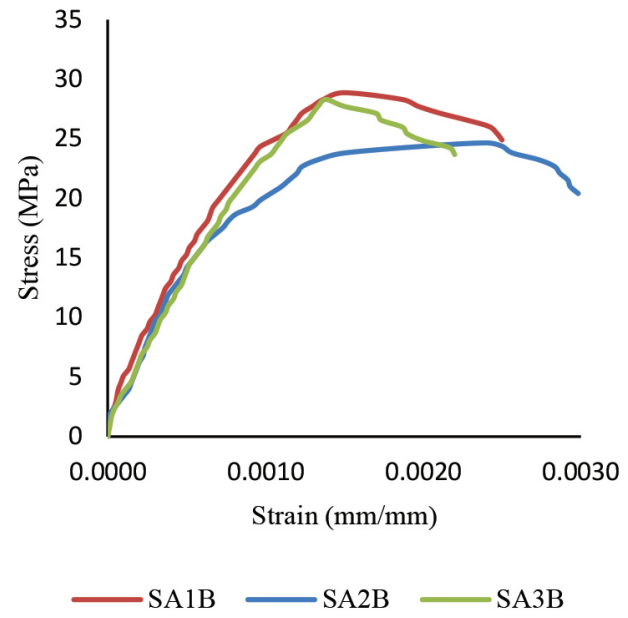

Figure 5: Stress and strain diagram of cylinder immersed fresh water in wet condition for 90 days.

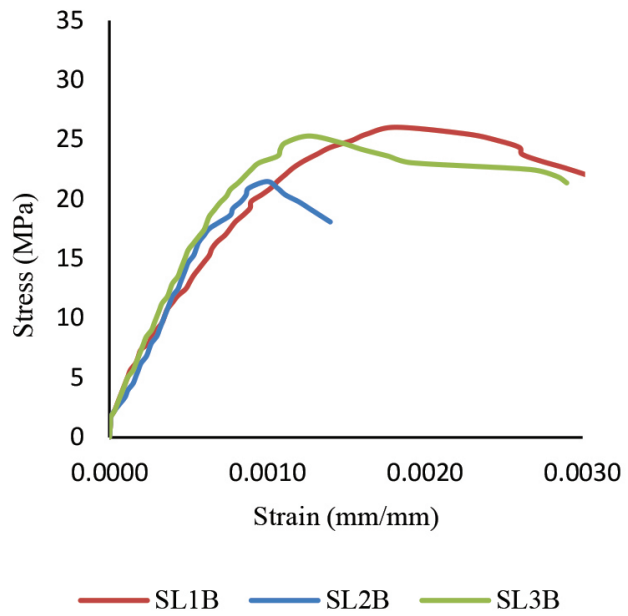

Figure 6: Stress and strain diagram of cylinder immersed seawater in wet condition for 90 days. 


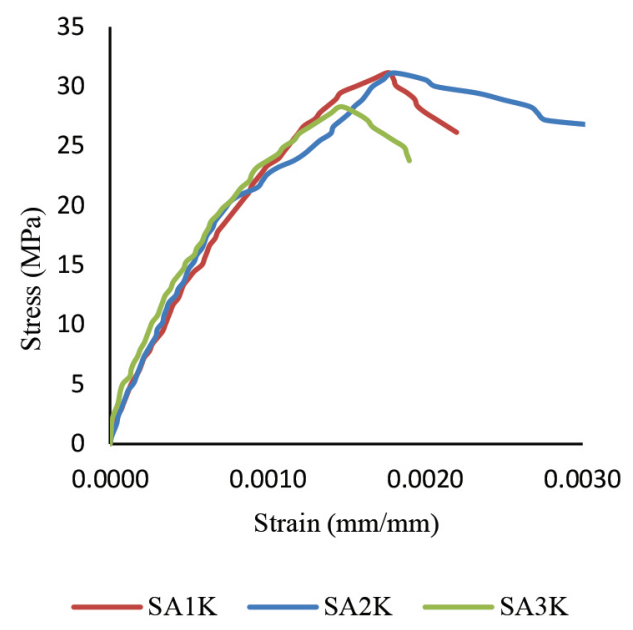

Figure 7: Stress and strain diagram of cylinder immersed fresh water in dry condition for 90 days.

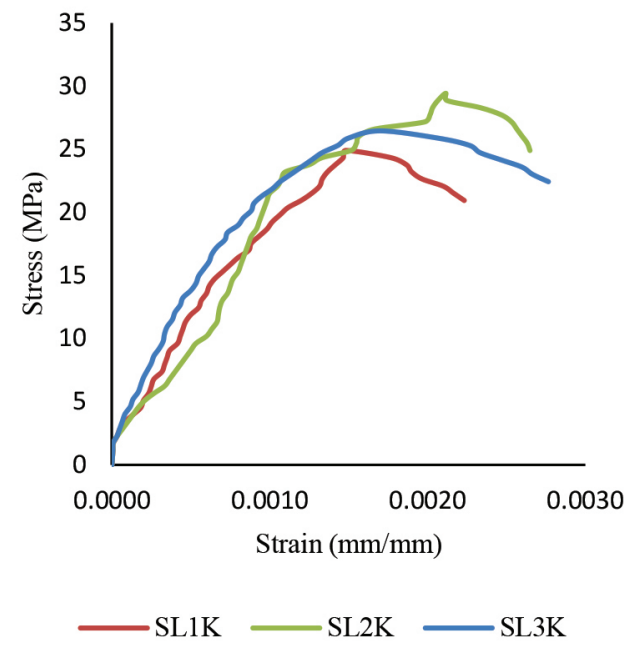

Figure 8: Stress and strain diagram of cylinder immersed seawater in dry condition for 90 days.

\subsection{Compression Strength of Concrete}

Observation of concrete cylinders in wet and dry conditions referred to previous theories and research. 
Table 4: Concrete cylinder in wet and dry conditions on day 28.

\begin{tabular}{ccccccc}
\hline Number & Code & $\begin{array}{c}\text { Wet } \\
\text { weight } \\
\text { condition }\end{array}$ & $\begin{array}{c}\text { Dry } \\
\text { weight } \\
\text { condition }\end{array}$ & Absorption & $\begin{array}{c}\text { Density } \\
\text { of wet } \\
\text { weight } \\
\text { condition }\end{array}$ & $\begin{array}{c}\text { Density of } \\
\text { wet weight } \\
\text { condition }\end{array}$ \\
\cline { 3 - 7 } & & $\mathrm{kg}$ & $\mathrm{kg}$ & $\%$ & $\left(\mathrm{~g} \mathrm{~cm}^{-3}\right)$ & $\left(\mathrm{g} \mathrm{cm}^{-3}\right)$ \\
\hline 1 & SA1K & 13.70 & 13.50 & 1.48 & 2406.92 & 2371.79 \\
2 & SA2K & 13.70 & 13.50 & 1.48 & 2556.86 & 2519.53 \\
3 & SA3K & 13.10 & 12.90 & 1.55 & 2446.56 & 2409.21 \\
4 & SL1K & 13.80 & 13.60 & 1.47 & 2603.07 & 2565.34 \\
5 & SL2K & 14.00 & 13.80 & 1.45 & 2605.93 & 2568.70 \\
6 & SL3K & 13.40 & 13.20 & 1.52 & 2553.15 & 2515.04 \\
7 & SL1B & 13.80 & NA & NA & 2533.26 & NA \\
8 & SL2B & 13.70 & NA & NA & 2584.29 & NA \\
9 & SL3B & 13.50 & NA & NA & 2786.28 & NA \\
10 & SA1B & 13.50 & NA & NA & 2546.48 & NA \\
11 & SA2B & 13.00 & NA & NA & 2445.64 & NA \\
12 & SA3B & 13.40 & NA & NA & 2517.65 & NA \\
\hline
\end{tabular}

Table 5: Concrete cylinder in wet and dry conditions on day 90.

\begin{tabular}{ccccccc}
\hline Number & Code & $\begin{array}{c}\text { Wet } \\
\text { weight } \\
\text { condition }\end{array}$ & $\begin{array}{c}\text { Dry } \\
\text { weight } \\
\text { condition }\end{array}$ & Absorption & $\begin{array}{c}\text { Density of } \\
\text { wet weight } \\
\text { condition }\end{array}$ & $\begin{array}{c}\text { Density of } \\
\text { wet weight } \\
\text { condition }\end{array}$ \\
\cline { 2 - 7 } & $\mathrm{kg}$ & $\mathrm{kg}$ & $\%$ & $\left(\mathrm{~g} \mathrm{~cm}^{-3}\right)$ & $\left(\mathrm{g} \mathrm{cm}^{-3}\right)$ \\
\hline 1 & SA1K & 13.60 & 13.40 & 1.49 & 2507.66 & 2470.78 \\
2 & SA2K & 13.50 & 13.30 & 1.50 & 2524.60 & 2487.20 \\
3 & SA3K & 14.00 & 13.80 & 1.45 & 2654.06 & 2616.15 \\
4 & SL1K & 11.50 & 11.30 & 1.77 & 2161.37 & 2123.78 \\
5 & SL2K & 12.00 & 11.80 & 1.69 & 2251.53 & 2214.00 \\
6 & SL3K & 11.00 & 10.80 & 1.85 & 2107.46 & 2069.14 \\
7 & SL1B & 10.80 & NA & NA & 2107.43 & NA \\
8 & SL2B & 11.50 & NA & NA & 2159.14 & NA \\
9 & SL3B & 12.00 & NA & NA & 2044.11 & NA \\
10 & SA1B & 13.70 & NA & NA & 2547.69 & NA \\
11 & SA2B & 13.00 & NA & NA & 2419.15 & NA \\
12 & SA3B & 13.00 & NA & NA & 2504.88 & NA \\
\hline
\end{tabular}




\subsection{Analysis of Test Result}

Experimental observations indicate that the strength of concrete immersed in seawater for 28 days increased by $3.56 \%$ in dry condition and $8.75 \%$ in wet conditions. This condition is consistent with the theory presented by Mehta and Monteiro, and Wegian and Falah that the presence of chloride in seawater can increase the strength of concrete by creating Friedel's salt reaction. ${ }^{1,6}$ Figure 9 shows that 90 days after immersion, the strength of the concrete immersed in seawater decreased by $12.44 \%$ in dry conditions and $12.36 \%$ in wet conditions. The decline is caused by the presence of microcrack that occurred in the pores of the concrete due to salt crystallisation and ettringite reaction. The results of this experiment support the theory proposed by several sources in terms of the effect of seawater content on the strength of concrete.

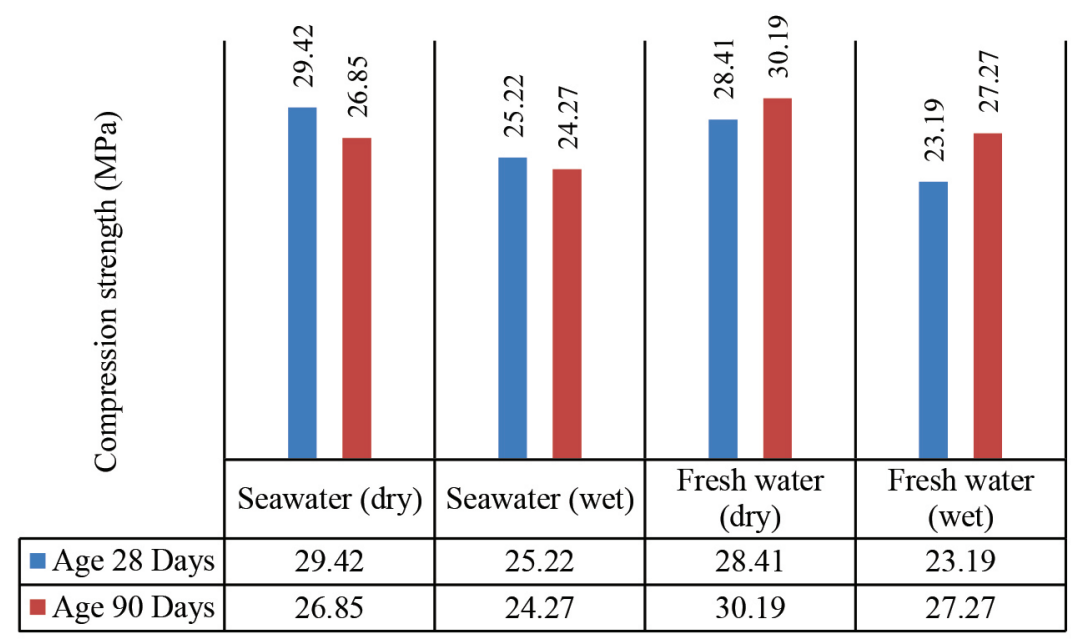

Figure 9: Comparison of concrete strength immersed in seawater and fresh water.

Some theories suggest that the strength of concrete is directly proportional to the life of the concrete. The concrete strength of the concrete specimens initially increased rapidly, but after 28 days, the increase became progressively slower. For comparison, the strength of concrete immersed in freshwater for 90 days increased by $6.26 \%$ in dry conditions and $17.57 \%$ in wet conditions from the strength at 28 days. The increase of concrete strength based on the age of the concrete can be seen in Figure 10 and Figure 11. The strength increase was influenced by the hydration process that occurs during the cement treatment. The strength of concrete immersed in seawater for 28 days and 90 days decreased by $9.58 \%$ in dry conditions and $3.92 \%$ in wet conditions. 


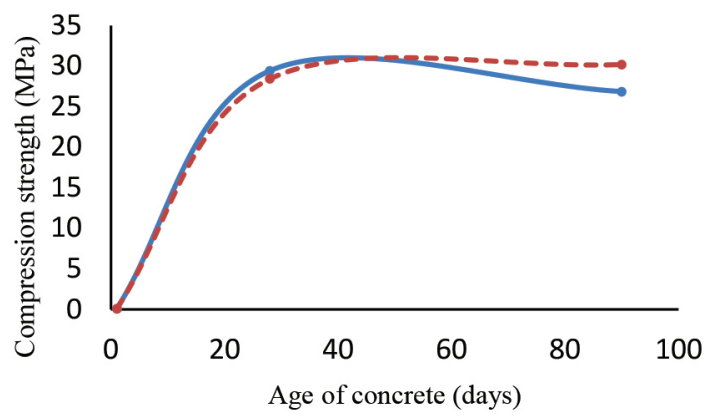

$\longrightarrow$ Sea Water $\quad-\cdots--$ Fresh Water

Figure 10: Relation of concrete strength and age in dry conditions.

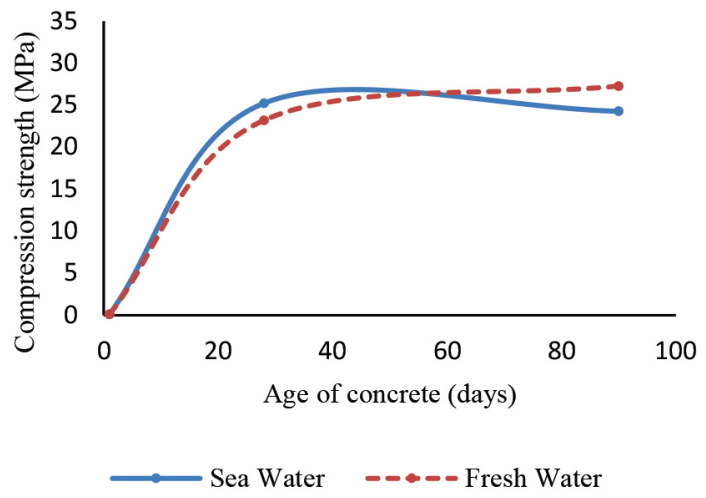

Figure 11: Relation of concrete strength and age in wet conditions.

Wet and dry conditions on concrete affect the strength of concrete. Based on Gao et al.'s explanation, the influence of sulphate in seawater can cause both macro and micro damage on concrete. ${ }^{5}$ Wet and dry conditions will impact the durability of concrete. From the experimental results, it can be seen that wet conditions, both immersed in seawater and fresh water, produced lower strength than in dry conditions. The strength of concrete immersed in fresh water declined by $10.64 \%$ and $10.72 \%$ on day 90 . Meanwhile, on day 28 , the strength of concrete immersed in seawater declined by $16.66 \%$ and $22.51 \%$. The results show that the scale is not much different from the research by Soroka and Baum. ${ }^{7}$ 


\section{CONCLUSION}

The present study supports the findings of previous research works and existing theories. Seawater content has a very serious effect on the shear strength of concrete. For up to 28 days, seawater content has a good impact on increasing the strength of concrete by chemical reactions in it. At 90 days, the results showed that the seawater content impacts the decline of concrete's strength. Wet and dry conditions affect the strength of concrete. The strength of concrete always in wet condition will decrease by $10 \%$ to $22 \%$. Therefore, it is necessary take considerations a number of aspects when planning a construction in an aggressive environment, especially in wet concrete conditions because it can reduce the strength of concrete as the concrete age increases.

\section{ACKNOWLEDGEMENTS}

The authors would like to thank all the staff, technicians and lab personnel of Universitas Gadjah Mada, Indonesia who have cooperated in the implementation of the experiments. This study was supported by Pt. Harmak Indonesia and Lembaga Pengelola Dana Pendidikan (LPDP), grant no. PRJ - 2272/ LPDP/ 2015.

\section{REFERENCES}

1. Mehta, P. K. \& Monteiro, P. J. M. (2006). Concrete: Microstructure, properties, and materials, 3rd ed. New York: McGraw-Hill.

2. Mbadike, E. M. \& Elinwa, A. U. (2011). Effect of salt water in the production of concrete. Nig. J. Technol., 30(2), 1-10.

3. Neville, A. M. (2011). Properties of concrete, 5th ed. London: Pitman.

4. Abualgasem, T., Cripps, J. C. \& Lynsdale, C. J. (2014). Effect of wetting and drying cycles on thaumasite formation in cement mortars. ASCE J. Mater. Civil Eng., 27(7), https://doi.org/10.1061/(ASCE)MT.1943-5533.0001083.

5. Gao, R., Li, Q.\& Zhao, S. (2013). Concrete deterioration mechanisms under combined sulphate attack and flexural loading. ASCE J. Mater. Civil Eng., 25(1), 39-44, https://doi.org/10.1061/(ASCE)MT.1943-5533.0000538.

6. Wegian, F. M. (2010). Effect of seawater for mixing and curing in structural concrete. IES J. A Civil Struct. Eng., 3(4), 235-243, https://doi.org/10.1080 /19373260.2010.521048.

7. Soroka. \& Baum, H. (1994). Influence of specimen size on effect of curing regime on concrete compressive strength. ASCE Civil Eng., 6(1),15-22. 